\title{
THE ANTHROPOLOGICAL VIEW OF THE LATVIAN WOMAN THROUGHOUT CENTURIES
}

Beginning with the $12^{\text {th }}$ century the great significance of the Daugava for trade between the East and the West has been discovered. In 1201 the pope confirmed the contract between bishop Albert (?-1229) and the Livs and this is regarded as the year of the foundation of Riga. The name "Riga" is founded in the Livonian chronicle "ad locum Riga" (Chron. Liv., 112-5). As a nation Latvians have developed from Baltic tribes, which had occupied this territory approximately 4000 years ago. A small nation, the existence of which is continuously being threatened, possesses the vital necessity to keep their national identity. That has never been an easy task taking into consideration our geopolitical situation as we occupy a place among mighty countries. Poles, Danes, Swedes, Lithuanians, Germans and Russians have been reigning here. Riga has always been a bridge between the East and the West. A small country may exist only by being self-conscious possessing a national pride and a high potential of spiritual values.

Since ancient times the Latvian women, were those who created the unique and colourful folk's costumes which surprised everybody with their variety, and throughout the borders of the various regions they existed as a value confirming their identity. The elements of each folk costume demanded creativity and skill to make it.

In the country inhabited by Latvians a mixture of various cultures and nations have been taking place for a long time. This determined the ethnic and anthropological variety of the Latvian people.

Since the end of the $19^{\text {th }}$ century and the beginning of the $20^{\text {th }}$ century scientists in the whole of Europe paid great attention to the determination of the anthropological investigations which date back to the year 1920, when the director of the Institute of anatomy and histology of Latvia's University professor Gaston Victor Backman (1883-1964) organised the first anthropological expeditions in order to perform anthropological measurements of Latvians. Already in the summer of 1920, the teachers of the Institute of anatomy and histology started taking part in expeditions and carried out work on anthropological research. The data obtained were scientifically worked up and research works written, 
which were published not only in Latvia, but also in other European countries (Vilde, 1924; Prīmanis, 1925).

A review of the published works about the built of the Latvian woman shows that they have been compiled centuries ago, although the somatoscopie characterisation is predominant.

In 1776, J. G. Georgi mentions Latvian women in his work "Beschreibung aller Nationen des Russischen Reiches", characterizing them as being beautiful and somewhat conceited.

In 1868 L. Brumiers, while describing Courland and its inhabitants, mentioned "that the Latvian people can be characterised as beautiful and well formed. Latvian women will cover their beautiful hair by headscarves, and it is a beautiful sight when the young, pretty face of a Latvian woman looks out through the scarf as if from a framed picture". ("...gewahrt ein anzienhendes Schauspiel wenn das junge reizende Gesicht einer Lettin aus dem Tuche, gleichsam wie aus einem Rahmen, hervorblickt".)

In 1878 in the work "Picturesque Russia" (Živopisnaja Rosija) under P. Semionoff's editorship the Latvian woman is characterised having a strong and proportional body built. The face is elongated with somewhat rough features, wide eyes, and a straight nose, with slightly protruding teeth and a wide chin. In $1879, \mathrm{O}$. Waeber was the first to systematise anthropological data about 40 Latvian women aged from 17 to 60 . The research was conducted in Kurzeme. The author characterises Latvian males and females in the following way: they are of medium height, often tall with a strong and proportionally built body. Obesity is rare. The skin is light, the hair - straight or slightly wavy, fair or light brown in colour, seldom darkbrown; black and red hair has not been observed. The colour of the eyes is either greyish blue, or grey and blue seldom brown. The eyes are of medium size, the slit is horizontal. The average index of the head is 80 for both sexes. The face is oval, without protruding cheekbones, it is seldom square or triangular. The nose is straight, comparatively long, the mouth is of average size, well formed with straight teeth, and the lips are full but not thick.

Professor Jēkabs Prīmanis (1892-1971) in 1929 described the exterior of Latvian women as depicted in folk songs. J. Prīmanis considers that the "Dainas" represent those characteristics which refer to the general appearance of the body. The "Dainas" mention two types of women. One is characterised by slight built, the second the dominating one is characterised by a low and rotund built. The author points out that nothing confirms obesity of Latvian woman, but it is connected with the rounded forms of the woman in general. The "Dainas" mention the pigmentation characteristics of the Latvian woman the colour of hair, eyes and skin. The colour of the hair is mostly fair, yellow, while black hair is seldom mentioned. The "Dainas" also describe "white and fair" skin. The forehead is usually broad and high. Big, wide eyes are more 

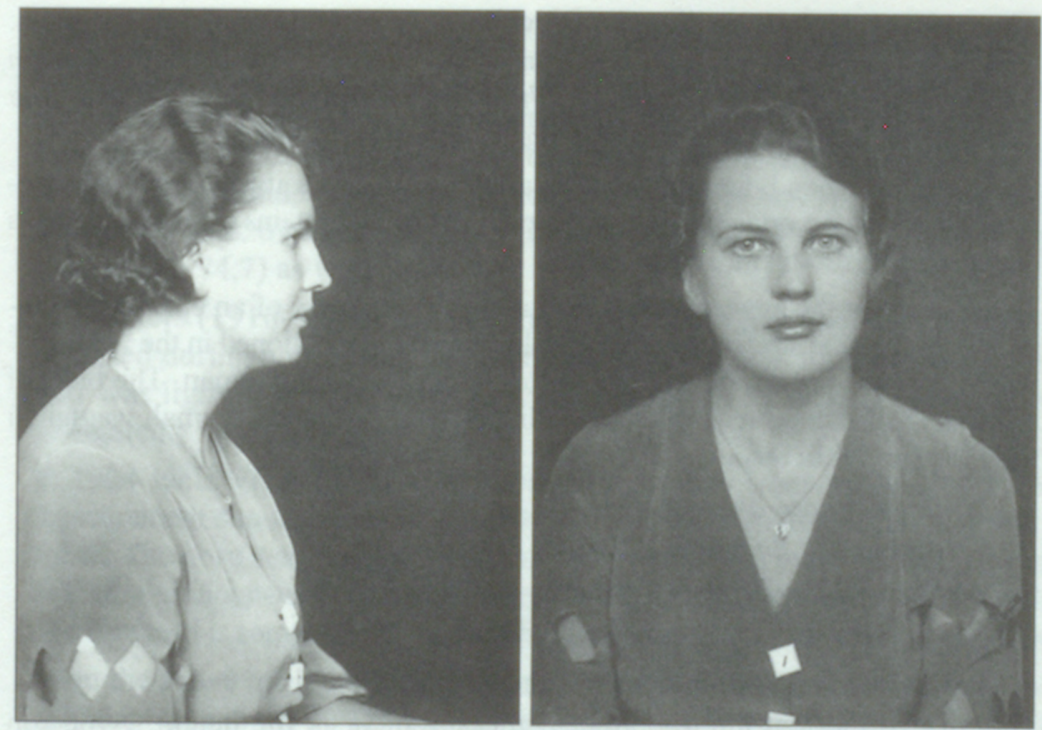

Specially made photographies were also used for anthropological measurements (frontal and side views). The 30 -ies of the $20^{\text {th }}$ century

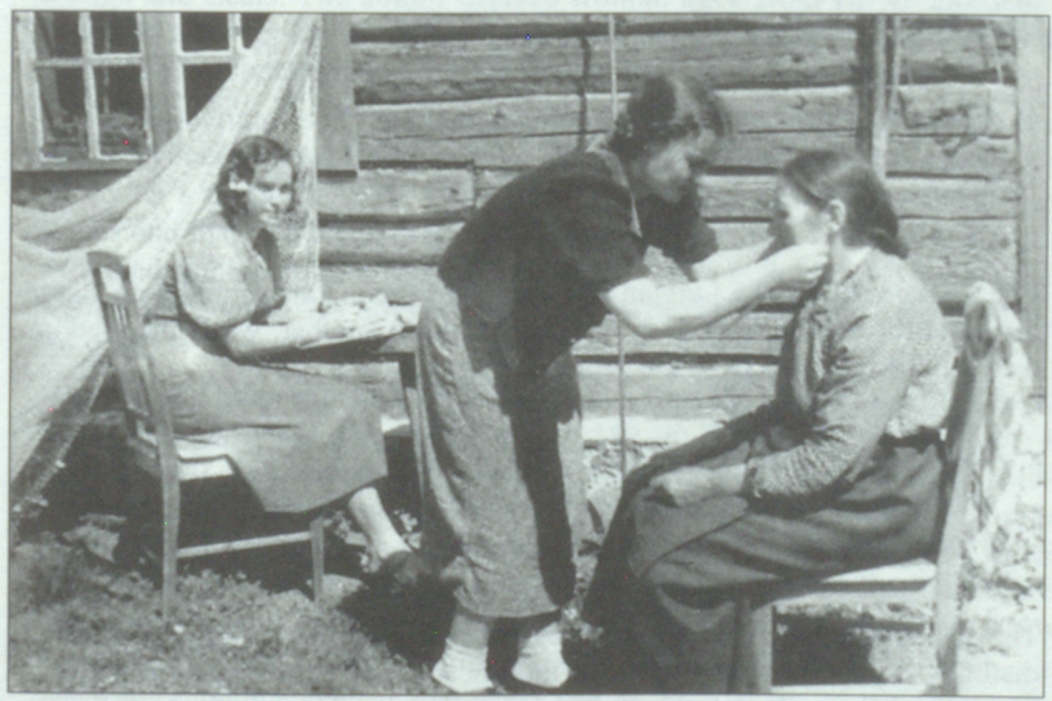

The scientific collaborates of an anthropological expedition perform anthropological measurements in Zvejniekciems - a village in Limbažu region. 1938 
often described than small and narrow ones. In conclusion Prīmanis notes: "Everything that leaves an impression of the outward appearance has been widely described in the "Dainas". These are characteristic features of the Latvian organism which are confirmed by scientific research".

Every nation when being mixed with another one loses its primeval, characteristic built of the organism, although each individual retains through century's one characteristic feature of its nation.

The data about the appearance of the Latvian woman are of an episodical character. We have to stress again that the oldest data are mentioned in the "Dainas" where we can find characteristics of the ancient Latvian woman. The built of a country girl has been compared to a linden tree, a squirrel, a small wagtail, a little rose or a thin reed.

My brothers are like oak trees,

My sisters like lindens, And I myself my brother's sister

Grow like a rose in the garden.

$$
\text { B. V. } 5398
$$

The most important anthropological measurement is the height. A person differs from another one and a nation from another one by the height of his body. Women are smaller than men by $10-12 \mathrm{~cm}$. The height is influenced not only by heredity, but by outer factors as well. One should note that the height changes with age.

Grand and stately is the tall linden tree

When her leaves have blossomed out.

More stately is our country girl

When she has reached her twentieth year.

B. V. 5308

The average height of a Latvian woman is $157,0 \mathrm{~cm}$. One should note that the height of the body passes from one generation to another, while the predominant will be inherited from the parents.

I grew up a big, big girl

From my little darling mother

When walking I can round a birch grove,

While standing count the stars in the sky.

$$
\text { B. V. } 5319
$$

The second characteristic anthropological indication is the head. We usually distinguish persons by the shape of their heads. With anthropological measurements we can calculate various indices. We can distinguish the following shapes (according to R. Martin) - dolichocephalia, mesocephalia, brachycephalia and hyperbrachycephalia. 
Each nation has its peculiar shape of the head. Each cultural-historical region in Latvia also possesses a peculiar shape of the head. J. Prīmanis in 1924 performed anthropological measurements of the skulls found in the region of Pāle (dated back to the $17 \mathrm{cen}$.). He found out that the dominating shape was brachycephalia (ind. 77,9). In the region of Bauska (11 cen.) - Dolichocephalia dominated (ind. 69,9) and in the region of Piebalga (13 - cen.) - dolichocephalia (ind. 74,7 ) as well.

Jānis Lĩcis (1910-1956) in 1933 describes the skulls found in Zemgale, obtained during archaeological studies arms, well developed muscles. The hair was light brown, the eyes grey of average size. Their shape is rather elongated.

In 1924 Jānis Vilde (1900-1971) described the Liv women age 20-72. The measurement showed a height of $160-161 \mathrm{~cm}$, wide shoulders, and the skin white. The nose was straight, rather big, the mouth - of average size, the state of teeth - orthognate. Pronounced sulcus mentolabialis and sulcus nasolabialis. The forehead is comparatively high. The skull is brachicephalic or mesocephalic.

From the above mentioned facts we may conclude that the analysis of anthropological data in the 20 -ies is based on a rather small number of observations.

A wider research including 1000 Latvian woman according to their anthropological signs was done by Lūcija Krastiṇa-Jēruma (1899-1968) in 1929-1930, in Riga and Cēsis. The author divides woman aged from 18-45 into 5 age groups. In these groups the author determines the somitoscopic signs of woman and their anthropometric indices.

L. Krastina-Jēruma is of the opinion that the Latvian anthropological type was formed by merging the Nothern Baltic and Eastern Baltic races. She defended her doctor's thesis in 1935. The work was awarded the prizes of Krišjānis Barons and that of the Cultural foundation. In 1926-1936 L. Krastina-Jêruma performed anthropological research of Latvian pupils in the Second gymnasium of Riga. She studied 299 boys and 563 girls by determining their height, weight and girth.

Vigorous and proportional body built characterises the Latvian woman; she is neither thin nor obese. Her height is over $159 \mathrm{~cm}$ (except in Latgale where it is $156,64 \mathrm{~cm}$ ). Fair, blond hair is characteristic for more than one half of the woman studied. The colour of eyes is mostly greyish blue or blue; brown eyes are rare. J. Prīmanis and N. Jērums (1904-1991) in 1924 collected data about the "Courlands Konini". 12 woman were inspected in the Kuldiga region and their height marked $155,3 \mathrm{~cm}$. J. Prīmanis in 1925 described 12 female skulls excavated in Pāles district dating back towards the 17-18 centuries. He found mesocranium typical for them. The average index of the length and breadth of the skulls was $77,76 \pm 1,17$. Dolichocranium was found in $27,3 \%$, mesocranium - in $36,3 \%$ and brachicranium in as many cases. 
Prīmanis notes that women are nearer to the acrocrane and hypsicrane group. $\mathrm{He}$ also concludes that the skulls found is Pāle belonging to the Latvian and Liv bastards, who lived along the seaside of Vidzeme. G. Knorre in 1930 researched 20 female skulls excavated in Latgale, which were identified from the 8 to the 12 centuries. In general the author characterises these skulls as dolichocranes in $50 \%$ of cases out of which $8,3 \%$ are hyperdolichocrania, $41,7 \%$ mesocrania and $8,3 \%$ brachicrania. Female skulls in length are orthocranes (of average height), while in width they are acrocranes.

In October 1997 the Institute of anatomy and anthropology was founded. This could be paralleled to the successful pre-war work by Jēkabs Prīmanis for the education of the youth and development of the state. Today we are safe to say that the connection between the pre-war period and modern research in anthropology has been created anew.

\section{References}

1. Prīmanis J. Latviešu ḳermeṇa uzbūve Latviju dainās // Latviju tautas dainas: 4 sēj. - Rīga, 1929. - 1-46. lpp.

2. Jêrums N., Vîtols T. Beiträge zur Anthropologie der Letten // LU Raksti. - 1928. -XVIII.

3. Prīmanis J. Pāles galvaskausi // LU Raksti. - 1925. - XII. - 429,-480. Ipp.

4. JêrumsN., PrīmanisJ. Kuršu ḳoniṇi. - 1925. [Rokraksts; glabājas Jēkaba Prīmaṇa Anatomijas muzejā.]

5. Vilde J. Materiāli par lỉbiešu antropologiju // LU Raksti. - 1924. - XI.

6. Martin R. Lehrbuch der Anthropologie. - Zweite Auflage. - Jena, 1928. -I u. II Bd.

7. Lindberga $R$. Museum Anatomiae Jacobi Primani. - Rīga, 1995.

8. Waeber $O$. Beiträge zur Anthropologie der Letten: Diss. - Dorpat, 1879.

9. Hempel F, Geissler. Abbildung und Beschreibung der Völker unter des russischen Kaisers Alexander Regierung. - Leipzig, 1803.

10. Lìcis J. Kraniologische Untersuchungen an Schädeln altlettischer Stämme. Rīga, 1939.

11. GeorgiJ.G. Beschreibungen aller Nationen des russisches Reiches. - St.Petersburg, 1776.

12. Knorre G. Kraniologische Untersuchungen an Schädeln aus Skelettgräbern Lettgalens // Ztsch. f. Morph. und Anthrop. - Stuttgart, 1930. - Bd. XXVIII. H. 3. - S. $256-312$.

13. Krastinna-Jêruma L. Latviete no antropologiskā viedok|a: Disertācija - Rīga, 1934. -275 Ipp.

\section{Dr. Ilva Dulevska}

Jēkaba Prīmaṇa Anatomijas muzejs, Kronvalda bulv. 9, Riga LV 1010, Latvia E-mail: museum2@mailbox.riga.lv 